\title{
Ponatinib miRNA İfadelerini Düzenleyerek Meme Kanseri Hücrelerini Hedefler
}

\author{
Çağla KAYABAŞı ${ }^{1}$, Sunde YILMAZ SÜSLÜER ${ }^{1}$, Tuğçe BALCI OKCANOĞLU ${ }^{2}$, \\ Besra ÖZMEN YELKEN ${ }^{3}$, Zeynep MUTLU ${ }^{1}$, Cansu ÇALIŞKAN KURT ${ }^{1}$, \\ Bakiye GÖKER BAĞCA ${ }^{4}$, Çığır BİRAY AVCI ${ }^{1}$, Cumhur GÜNDÜZ ${ }^{1}$
}

1 Ege Üniversitesi Tıp Fakültesi, Tıbbi Biyoloji Anabilim Dalı, İzmir.

2 Yakın Doğu Üniversitesi, Sağlık Hizmetleri Meslek Yüksekokulu, Lefkoşa, KKTC.

3 İzmir Bakırçay Üniversitesi Tıp Fakültesi, Tıbbi Biyoloji Anabilim Dalı, İzmir.

4 Aydın Adnan Menderes Üniversitesi Tıp Fakültesi, Tıbbi Biyoloji Anabilim Dalı, Aydın.

\section{ÖZET}

Meme kanseri kadınlarda en yaygın gözlenen kanser türüdür. Mevcut tedavilerin düşük seçicilik ya da zamanla oluşan ilaç direnci gibi eksiklerini giderebilecek yeni stratejilerin belirlenmesine ihtiyaç vardır. Çalışmamızda, çoklu hedefli bir tirozin kinaz inhibitörü olan ponatinibin meme kanseri hücreleri üzerindeki anti-kanser etkisini değerlendirmeyi ve ponatinib yanıtında yer alan miRNA'ların biyoinformatik yaklaşım ile sinyal yolaklarındaki potansiyel işlevini tanımlamayı hedefledik. Bu amaçla, MCF-7 hücrelerinde ponatinibin sitotoksik etkileri xCELLigence ile gerçek-zamanlı olarak belirlendi. Ponatinib uygulaması sonrasında apoptoz, proliferasyon hızı, hücre döngüsündeki değişimler akım sitometriyle, miRNA'ların ifadelerindeki düzenlenmeler qRT-PCR ile değerlendirildi. İfadelerinde anlamlı değişim belirlenen miRNA'ların ilişkili olduğu olası mRNA'lar ve sinyal yolakları KEGG yolak analizi ile tanımlandı. Ponatinibin MCF-7 hücreleri üzerinde sitotoksik etkiye sahip olduğu $\left(\mathrm{IC}_{50}: 4,59 \mu \mathrm{M}\right)$ belirlendi. Ponatinib uygulaması ile MCF-7 hücrelerinde anlamlı olarak apoptozun indüklendiği, proliferasyonun baskılandığı ve hücre döngüsünün $\mathrm{G}_{0} / \mathrm{G}_{1}, \mathrm{~S}$ evrelerinde durakladığı belirlendi. Ayrıca, let-7a-5p, miR-29a-3p, miR-7-5p, miR-125b-5p, miR-212-3p ifadelerinde artış ( $<<0,05)$, miR-210-3p, miR-19b-3p, miR-140-5p, miR-181b-5p, miR-155-5p, miR-223-3p, miR-141-3p, miR-21-5p ifadelerinde azalma olduğu $(\mathrm{p}<0,05)$, miR-19a-3p ifadesinin ise tamamen baskılandığı belirlendi. Biyoinformatik analizler ile, ifadesi değișen miRNA'ların kanserde proteoglikanlar, Hippo, p53, TGF-beta, kanser-ilișkili, PI3K-Akt, prolaktin, hücre döngüsü, östrojen, mTOR sinyal yolakları ile ilişkili olduğu ortaya koyuldu. Ponatinib uygulaması meme kanseri hücrelerinde apoptozu indükleyerek, proliferasyonu baskılayarak ve hücre döngüsünü durdurarak güçlü anti-kanser aktivite sergilemiş̧tir. Ponatinibin belirlenen anti-kanser etkilerinde miRNA'ların rolleri olabileceği gösterilmiștir. Olası miRNA-mRNA etkileşimleri ile meme kanserindeki hedef sinyal yolaklarının tanımlanması ışığında, ponatinibin tek başına veya diğer tedavilerle kombinasyon halinde meme kanseri tedavisi için potansiyel bir strateji olabileceği görüşündeyiz.

Anahtar Kelimeler: Meme Kanseri. MCF-7 Hücre Hattı. Ponatinib. miRNA. Apoptoz. Proliferasyon. Hücre Döngüsü.

Ponatinib Targets Breast Cancer Cells by Regulating miRNA Expressions

\begin{abstract}
Breast cancer is the most common cancer in women. There is a need to identify novel strategies that can overcome the failure of existing treatments, such as low selectivity or drug-resistance. In our study, we aimed to evaluate the anti-cancer effect of ponatinib, a multi-targeted tyrosine kinase inhibitor, on breast cancer cells and to define the potential function of miRNAs involved in the ponatinib response in signaling pathways with bioinformatics analysis. For this purpose, the cytotoxic effects of ponatinib on MCF-7 cells were measured in real-time by xCELLigence. After ponatinib treatment, changes in apoptosis, proliferation, cell-cycle regulation were evaluated by flow cytometry, and the regulations of miRNAs were evaluated by qRT-PCR. mRNAs and signaling pathways interacted with miRNAs that significantly changed were predicted by KEGG pathway analysis. It was determined that ponatinib had a cytotoxic effect $\left(\mathrm{IC}_{50}: 4.59 \mu \mathrm{M}\right)$ on MCF-7 cells. After ponatinib treatment, it was determined that apoptosis was induced, proliferation was suppressed and the cell-cycle was arrested at the $\mathrm{G}_{0} / \mathrm{G}_{1}$ and S phases significantly in MCF-7 cells. Ponatinib up-regulated let-7a-5p, miR-29a-3p, miR-7-5p, miR-125b-5p, miR-212-3p expressions $(p<0,05)$. Following the ponatinib exposure, miR-210-3p, miR-19b-3p, miR-140-5p, miR-181b-5p, miR-155-5p, miR-223-3p, miR-141-3p, miR-21-5p were down-regulated $(p<0,05)$ while the expression of miR-19a-3p was completely suppressed. Bioinformatics analyzes revealed that ponatinib-regulated miRNAs are associated with proteoglycans in cancers, Hippo, p53, TGF-beta, cancer-related, PI3K-Akt, prolactin, cell-cycle, estrogen, mTOR signaling pathways. Ponatinib treatment exhibited potent anti-cancer activity by inducing apoptosis, suppressing proliferation and blocking the cell-cycle progression in breast cancer cells. It has been shown that miRNAs play roles in the anti-cancer efficiency of ponatinib. In light of the identification of target signaling pathways based on the predicted miRNA-mRNA interactions, we believe that ponatinib alone or in combination with other treatments may be a potential strategy for the treatment of breast cancer.
\end{abstract}

Key Words: Breast Cancer. MCF-7 Cell Line. Ponatinib. miRNA. Apoptosis. Proliferation. Cell Cycle. 
Geliş Tarihi: 06.Ekim.2021

Kabul Tarihi: 02.Kasım.2021

* "39th Congress of the Federation of European Biochemical Societies (FEBS) EMBO 2014 Conference" toplantısında (30 Ağustos - 4 Eylül 2014, Paris, Fransa) poster bildiri; XVII. Tıbbi Biyoloji ve Genetik Kongresi'nde (28 31 Ekim 2021, çevrimiçi) poster bildiri olarak sunulmuştur.

Dr. Çağla KAYABAŞI

Ege Üniversitesi Tıp Fakültesi,

Tıbbi Biyoloji Anabilim Dalı, İzmir.

Tel: 02323902260

E-posta: kayabasicagla@gmail.com

Kadınlarda en yaygın gözlenen kanser türü olan meme kanseri, kontrolsüz hücre proliferasyonu ile karakterize heterojen bir hastalıktır ${ }^{1,2}$. Meme kanseri 2019 istatistiklerine göre, kadınlarda kanser ilişkili ölümler arasında akciğer kanseri sonrasında ikinci sırada yer almaktadır ${ }^{2}$. Meme kanseri olgularının çoğunluğunda pozitif olan östrojen reseptörü (ÖR) belirli genlerin ifadelerini düzenleyerek meme kanseri gelişiminde kritik rol oynamaktadır ${ }^{3}$. Günümüzde meme kanserinin tedavisinde cerrahi müdahale, radyoterapi, hormon tedavisi, immünoterapi ve kemoterapi uygulanmakta$\mathrm{d}_{1} \mathrm{r}^{1,4}$. Ancak mevcut ilaçların seçiciliği düşük olabilmekte ya da tedavi sürecinde ilaçlara zamanla direnç gelişebilmektedir ${ }^{1}$.

Vasküler endotelyal büyüme faktörü reseptörü (VEGFR), platelet kaynaklı büyüme faktörü reseptörü (PDGFR), fibroblast büyüme faktörü reseptörü (FGFR) düzenlenmelerindeki bozulmalar meme kanseri için belirgin risk faktörleridir, bu nedenle meme kanseri tedavisinde potansiyel hedef teşkil ederler ${ }^{5-7}$. Ponatinib, esasen kronik myeloid lösemi tedavisinde T315I mutasyonu taşıyan BCR-ABL1 füzyon proteini hedeflemek için tasarlansa da Src ailesi kinazları, cKit, VEGFR2, PDGFR $\alpha$, FGFR1 gibi kinazlar1 da güçlü şekilde inhibe edebilmektedir ${ }^{8-10}$. Bu kinazların önemli rol oynadığı meme, tiroid, yumurtalık, akciğer kanserleri üzerinde ponatinibin etkinliği değerlendirilmiştir ${ }^{11}$.

MikroRNA'lar (miRNA'lar), 19-25 nükleotid uzunluğunda tek zincirli kodlanmayan RNA molekülleridir. Hedef mRNA'lara kismi veya tam komplementer baz eşleşmesi yoluyla 3'UTR'den bağlanarak mRNA'ların translasyonlarının baskılanmasına veya yıkımlarına neden olurlar. miRNA'lar büyüme, farklılaşma, stres tepkisi, proliferasyon, apoptoz, otofaji gibi biyolojik süreçlere ek olarak malignitelerin gelişimi, metastazı, prognozu ve ilaç direnci ile de yakından ilişkilidir ${ }^{12,13}$. Farklı kanserlerde, miRNA'ların hem tümör baskılayıcı hem de onkogenik aktiviteye sahip olabildikleri gösterilmiştir ${ }^{14}$. Meme kanserinde de tümör baskılayıcı ve onkogen olarak rol oynayan çok sayıda miRNA tanımlanmıştır ${ }^{15}$.

Dünya genelinde yüksek insidans ve mortaliteye sahip meme kanserinin mevcut tedavilerin eksiklerini giderebilecek yeni stratejilerin tanımlanmasına ihtiyaç

\section{Yazarların ORCID Bilgileri:}

Çağla KAYABAŞI: 0000-0002-6797-7655

Sunde YILMAZ SÜSLÜER: 0000-0002-0535-150X

Tuğçe BALCI: 0000-0003-0613-765X

Besra ÖZMEN YELKEN: 0000-0002-0659-1097

Zeynep MUTLU: 0000-0003-3722-4430

Cansu ÇALIŞKAN KURT: 0000-0003-3397-6854

Bakiye GOKER BAGCA: 0000-0002-5714-7455

Çığır BİRAY AVCl: 0000-0001-8251-4520

Cumhur GÜNDÜZ: 0000-0002-6593-3237

vardır. Bu nedenle çalışmamızda, meme kanseri olgularının büyük çoğunluğunu oluşturan ÖR pozitif grubunun in vitro hedeflenmesinde ponatinibin rolünü araştırdık. Ponatinibin meme kanseri üzerindeki etkileri ile ilgili çeşitli çalışmalar yapılmasına rağmen miRNA ekspresyon profili üzerindeki etkisi büyük ölçüde bilinmemektedir. Bu nedenle çalışmamızda, ÖR pozitif meme kanseri hücrelerinde ponatinib yanıtında rol alan miRNA'ları ve sinyal yolakları ile ilişkilerini KEGG yolak analizi ile tanımlamayı amaçladık.

\section{Gereç ve Yöntem}

\section{Hücre Kültürü}

In vitro çalışmamızda, ÖR pozitif insan meme kanseri hücre hatt1 olarak MCF-7 (Katalog No:HTB-22, ATCC, Manassas, ABD) kullanıldı. Hücreler \%10 Fetal Sığır Serumu, 2mM L-glutamin, 100U/mL penisilin, $0,1 \mathrm{mg} / \mathrm{mL}$ streptomisin içeren RPMI-1640 medyumu (Biological Industries, Beit-Haemek, İsrail) ile $37^{\circ} \mathrm{C}$ 'de, $\% 95$ nem ve $\% 5 \mathrm{CO}_{2}$ 'li etüvde inkübe edildi. Ponatinib (\#S1490, Selleckchem, Houston, Teksas, ABD) final konsantrasyonu $10 \mathrm{mM}$ olacak şekilde dimetil sülfoksit ile çözülerek stok solüsyon hazırland1.

\section{Sitotoksisite Analizleri}

Ponatinibin hücrelerin \%50'sini öldürdüğü $\left(\mathrm{IC}_{50}\right)$ sitotoksik dozu gerçek-zamanlı hücre analiz sistemi (RTCA-xCELLigence, Roche, Berlin, Almanya) kullanılarak belirlendi. Sistem deneyler süresince her 15 dakika bir empedans kaydı gerçekleştirdi. Hücreler, 96 kuyucuklu E-plaklara üç tekrarlı olarak ekildi $\left(1 \times 10^{5}\right.$ hücre). İnkübasyon sonrasinda hücreler, ponatinib $(3,13-100 \mu \mathrm{M})$ ardışık artan dozları ile 72 saat süresince muamele edildi. Sitotoksisite, "xCELLigence RTCA yazılımı" analiz programında sigmoidal dozyanıt eğrisi ile $\left[\mathrm{Y}=\right.$ bottom $+($ top-bottom $) / \quad\left(1+10^{\wedge}\right.$ $\left[\left(\operatorname{LogIC}{ }_{50}-\mathrm{X}\right) \times\right.$ HillSlope $\left.)\right]$ hesapland 1 .

\section{Apoptoz Analizleri}

Ponatinibin apoptotik etkileri akım sitometride (Accuri C6, Becton Dickinson) araştırıldı. MCF-7 hücreleri 


\section{Meme Kanserinde Ponatinib İlişkili miRNA'lar}

6-kuyucuklu plaklara $5 \times 10^{5}$ hücre/kuyucuk olacak şekilde ekildi ve 24 saat inkübe edildi. Sonrasında, hücreler 72 saat süresince ponatinibin $\mathrm{IC}_{50}$ dozu ile muamele edildi. Ponatinib uygulanmayan kuyucuklar kontrol olarak kabul edildi.

Fosfatidilserin Eksternalizasyonu ve Membran Bütünlüğü Ölçümü

Apoptotik hücrelerdeki fosfatidilserin eksternalizasyonu ve membran bütünlüğü "FITC Annexin V Apoptosis Detection" Kit (BD Pharmingen, San Diego, CA, ABD) kullanılarak ölçüldü. Deney sonunda hücreler kit protokolüne uygun olarak Annexin V/PI ile boyanarak akım sitometride analiz edildi.

Apoptotik DNA Fragmantasyonu Ölçümü

Apoptotik hücrelerde DNA fragmantasyonu "APODIRECT” Kit (BD Pharmingen) kullanılarak ölçüldü. Belirtilen dozlara maruz birakılan hücreler kit protokolüne uygun olarak, \%1 paraformaldehit ile fikse edildi ve \%70 soğuk etanolde inkübe edildi. Yıkama basamaklarından sonra reaksiyon tamponu, TdT enzimi ve FITC-dUTP içeren solüsyonda süspanse edildi. Reaksiyonun durdurulması sonrasında PI/RNase boyama tamponunda inkübe edilerek 3 saat içinde akım sitometride analiz edildi.

\section{Proliferasyon Analizi}

MCF-7 hücrelerinin proliferasyon hızı karboksifloresan diasetat süksinimid ester (CFSE) boyama ile ölçüldü. MCF-7 hücreleri deney öncesinde $10 \mu \mathrm{M}$ CFSE (BD Pharmingen) ile boyandı. CFSE ile boyanmış MCF-7 hücreleri 6-kuyucuklu plaklara $5 \times 10^{5}$ hücre/kuyucuk olacak şekilde ekildi ve 24 saat inkübe edildi. Sonrasında, hücreler 72 saat ponatinibin $\mathrm{IC}_{50}$ dozu ile muamele edildi. Madde uygulanmayan kuyucuklar kontrol olarak kabul edildi. Colcemid (100 $\mathrm{ng} / \mathrm{ml}$, Biological Industries) ile muamele edilen hücreler pozitif kontrol olarak kabul edildi. Hücreler akım sitometriyle analiz edilerek yeşil floresan yoğunluk değişimine göre hücre proliferasyon hızı gösterildi.

\section{Hücre Döngüsü Analizi}

Ponatinibin $\mathrm{IC}_{50}$ dozunun hücre döngüsü üzerine etkileri akım sitometride araştırıldı. Bu amaçla MCF-7 hücreleri 6-kuyucuklu plaklara $5 \times 10^{5}$ hücre/kuyucuk olacak şekilde ekilerek 24 saat inkübe edildi. Süre sonunda, hücreler 72 saat ponatinib ile muamele edildi. Madde uygulanmayan kuyucuklar kontrol olarak kabul edildi. Deney sonunda hücreler, "Cycletest Plus DNA Reagent" Kit (BD Pharmingen) protokolüne uygun olarak hazırlandı ve akım sitometride analiz edildi.

\section{miRNA Ifadelerinin Belirlenmesi}

Ponatinibin miRNA ifade profili üzerine etkileri qRTPCR ile değerlendirildi. Bu amaçla MCF-7 hücreleri
$25 \mathrm{~cm}^{2}$ flasklara $1 \times 10^{6}$ hücre olacak şekilde ekildi ve 24 saat inkübe edildi. Sonrasında, hücreler 72 saat ponatinibin $\mathrm{IC}_{50}$ dozu $(4,59 \mu \mathrm{M})$ ile muamele edildi. Madde uygulanmayan hücreler kontrol grubu olarak kabul edildi. Deney sonunda hücreler toplanarak “miRNeasy Mini”" Kit (Qiagen, Hilden, Germany) ile total RNA izolasyonu gerçekleştirildi. RNA örneklerinin miktarı ve kalitesi spektroforometre ile (NanoDrop 1000, NanoDrop Technologies, Wilmington, DE, USA) ölçüldü. RNA örneklerindeki olgun miRNA'lar "miScript II Reverse Transcriptase RT" kit (Qiagen) kullanılarak cDNA'ya dönüştürüldü. Elde edilen cDNA'lar kullanılarak, primerleri "miScript miRNA PCR Array Human Breast Cancer" (Katalog No:MIHS-109Z, Qiagen) plaklarına gömülü 84 miRNA'nın ifadeleri gerçek zamanlı kantitatif RT-PCR ile kantite edildi. SNORD61, SNORD68, SNORD72, SNORD95, SNORD96A ve RNU6-2 normalizasyon için kullanıldı. Kontrole göre kat değişimleri $2^{-\Delta \Delta C t}$ formülü ile hesaplandı. Kat değişimi $\geq \pm 2$, ve p değeri $<0,05$ olan miRNA'ların ifadelerindeki değişimler anlamlı kabul edildi.

\section{Biyoinformatik Analizler}

İfadelerinde anlamlı değişim belirlenen miRNA'ların ilişkili olduğu mRNA'lar ve sinyal yolakları kyoto encyclopedia of genes and genomes (KEGG) yolak analizi ile DIANA miRPath v. 3 veri tabanında analiz edildi $^{16}$. DIANA miRPath veri tabanı kullanılarak Tarbase veri tabanı üzerinden, miRNA'ların hedef sinyal yolaklarına ait $\mathrm{p}$ değerleri 'Fisher'ın birleşik olasılık testi" ile belirlendi ve $p$ değeri $<0,05$ anlamlı kabul edildi.

\section{İstatistiksel Analizler}

MCF-7 hücre hattı ile yaptığımız deneylerden elde ettiğimiz sonuçların istatistiksel olarak karşılaştırılmas1 "GraphPad Prism" programı ile gerçekleştirildi. İkili karşılaştırmalar Student's t-test ile ve gruplar arasındaki farklılıklar tek yönlü ANOVA varyans analizi yapılarak belirlendi. Anlamlılık değeri $\mathrm{p}<0,05$ olarak alınd.

\section{Bulgular}

Ponatinibin MCF-7 Hücreleri Üzerindeki Sitotoksik Etkileri

Ponatinibin MCF-7 hücreleri üzerindeki sitotoksik etkileri gerçek-zamanlı hücre analiz sistemi xCELLigence ile değerlendirildi. MCF-7 hücreleri için ponatinibin 48. saatteki $\mathrm{IC}_{50}$ dozu 9,51 $\mu \mathrm{M}$ (Şekil 1), 72. saatteki $\mathrm{IC}_{50}$ dozu ise önceki çalışmamızda belirtiği üzere, 4,59 $\mu \mathrm{M}$ olarak hesapland ${ }^{17}$. 


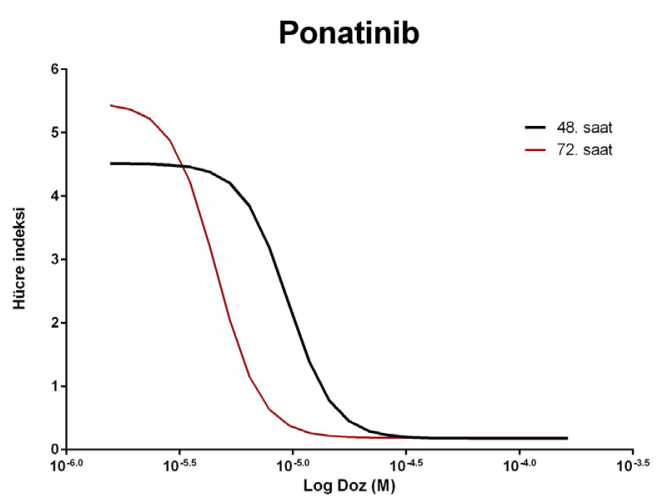

Şekil 1.

Ponatinibin MCF-7 hücreleri üzerindeki sitotoksik etkisi. Ponatinibin artan dozları hücreler ile 48 veya 72 saat boyunca kültüre edildi. $\log (d o z)$-hücre indeksi eğrileri, $x$ CELLigence ile hesaplandı. Sonuçlar, üç bağımsız deneyin ortalamalarıdır.

\section{Ponatinibin MCF-7 Hücreleri Üzerindeki Apoptotik Etkileri}

MCF-7 hücrelerine 72 saat süreyle $4,59 \mu \mathrm{M}$ ponatinib uygulamasının apoptotik etkinliği değerlendirildi. Annexin V/PI boyama sonuçlarına göre, kontrol grubunda canlı hücre yüzdesi $\% 92,59$ iken erken ve geç apoptotik hücre yüzdesi toplamı $\% 4,46$ olarak saptand. Ponatinib uygulanan grupta ise canlı hücre yüzdesi $\% 53,9$ iken erken ve geç apoptotik hücre yüzdesi toplamı \%44,6 olarak saptandı (Şekil 2a). Ponatinib uygulamasının MCF-7 hücrelerinde apoptozu anlamlı olarak kontrole kıyasla 10 kat indüklediği saptandı $(p<0,0001)$. Artışın erken apoptotik aşamada olduğu belirlendi. Ayrıca, MCF-7 hücrelerinde apoptoz DNA fragmantasyonu ölçümü ile incelendi. Buna göre, kontrol grubunda apoptotik hücre yüzdesi $\% 0,9$ iken ponatinib uygulanan grupta apoptotik hücre yüzdesi \%3,3 olarak saptandı (Şekil 2b). Ponatinib uygulamasının MCF-7 hücrelerinde kontrole kiyasla apopto$\mathrm{zu}$ anlamlı olarak 3,7 kat arttırdığ 1 teyit edildi $(\mathrm{p}<0,0001)$.

\section{Ponatinibin MCF-7 Hücreleri Üzerindeki Anti- proliferatif Etkileri}

Ponatinibin MCF-7 hücreleri üzerindeki antiproliferatif etkileri CFSE boyama ile akım sitometride değerlendirildi. Doz uygulanmayan kontrol grubu hücrelerinin proliferasyonu $\% 50$ olarak kabul edildiğinde, 4,59 $\mu \mathrm{M}$ ponatinib uygulanan hücre grubunda proliferasyonunun \%3,76 olduğu belirlendi (Şekil 3). Ponatinibin 72 saat sonunda MCF-7 hücre proliferasyon hızını kontrole kıyasla 13,3 kat azalttığ koyuldu $(p<0,0001)$. Pozitif kontrol olarak kabul edilen, hücre döngüsü inhibitörü colcemid uygulanan hücre grubunda proliferasyonun 19,3 kat azalma ile klyaslandığında $\quad(p<0,0001)$, ponatinibin antiproliferatif etkinliği oldukça yüksek olarak değerlendirildi. a

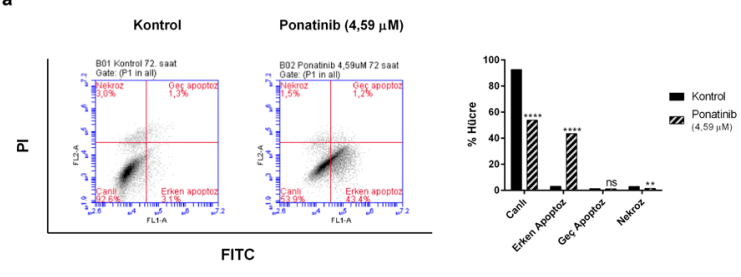

b

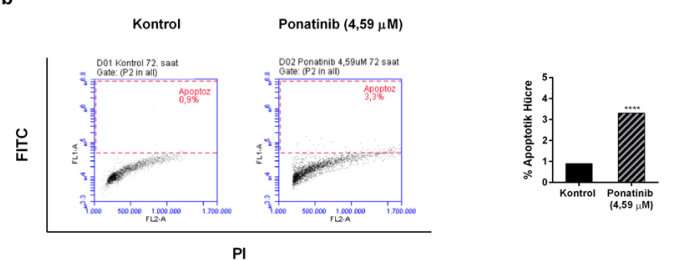

Şekil 2.

Ponatinibin MCF-7 hücreleri üzerindeki apoptotik etkileri. MCF-7 hücreleri, ponatinib $\left(I C_{50}: 4,59 \mu M\right)$ ile 72 saat süresince kültüre edildi $(n=3)$. Apoptoz indüksiyonu, akım sitometri kullanılarak (a) Annexin V/PI boyaması (b) DNA fragmantasyonu ölçümü ile belirlendi. Barların üzerindeki yıldızlar (*), kontrol ile karşılaş̧tırıldı̆ğnda anlamlı olan farklılıkları göstermektedir $\left(* * * * p<0,0001,{ }^{* *} p<0,01, n s p>0,05\right)$.
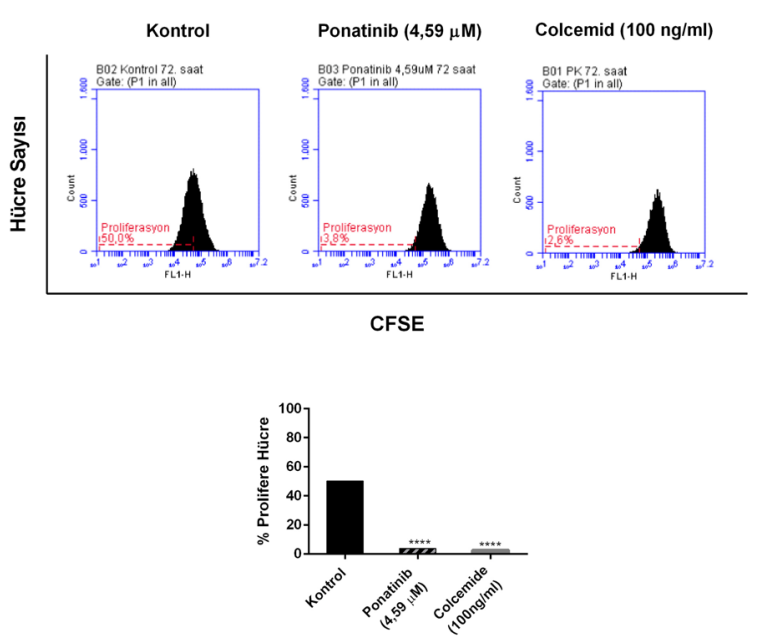

Sekil 3.

Ponatinibin MCF-7 hücre proliferasyonu üzerine etkileri. CFSE boyamasindan sonra ponatinib $\left(I C_{50}\right.$ : 4,59 $\mu \mathrm{M}$ ) ile 72 saat süresince kültüre edilen $\mathrm{MCF}-7$ hücrelerinin ( $n=3)$ proliferasyon hızlarl akım sitometride ölçüldü. Colcemid ile muamele edilmiş hücreler pozitif kontrol olarak ve negatif kontrol olarak CFSE ile boyanmamış hücreler negatif kontrol olarak kullanuldr. Barlarin üzerindeki yıldızlar (*), kontrol ile karşılaştırıldığında anlamlı olan farklllıklarl göstermektedir $(* * * * p<0,0001)$.

Ponatinibin MCF-7 Hücre Döngüsü Üzerindeki Etkileri

Hücre proliferasyonunu durdurduğunu belirlediğimiz ponatinibin MCF-7 hücre döngüsü düzenlenmesi üzerinde etkileri akım sitometride değerlendirildi. 
Kontrol grubunda hücrelerin $\mathrm{G}_{0} / \mathrm{G}_{1}$ fazındaki hücrelerin yüzdesi $\% 77,37$ ve $S$ fazındaki hücrelerin yüzdesi \%11,29 iken, ponatinib $(4,59 \mu \mathrm{M})$ uygulanan hücrelerde sirasiyla $\% 83,07$ ve $\% 13,78$ olarak saptand (Şekil 4). Ponatinibin 72 saat sonunda anlamlı düzeyde $G_{0} / G_{1}$ ve $S$ tutulumuna neden olduğu ve bu birikime $G_{2} / M$ fazında azalmanın eşlik ettiği belirlendi $(\mathrm{p}<0,0001)$. Bu sonuçlar ile ponatinibin MCF-7 hücre döngüsü progresyonunu $G_{0} / G_{1}$ ve $S$ fazlarında blokladığı ortaya koyuldu.

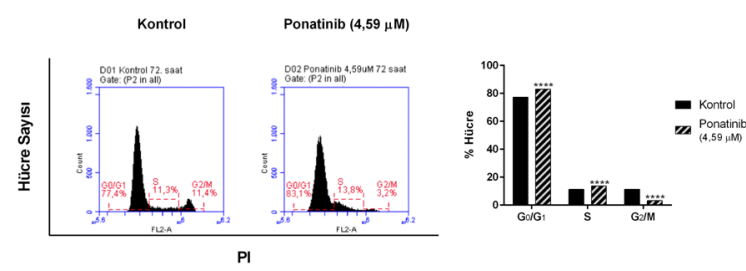

Şekil 4.

Ponatinibin MCF-7 hücre döngüsü üzerindeki etkileri. MCF-7 hücreleri, ponatinib (IC $50: 4,59 \mu M)$ ile 72 saat süresince kültüre edildi $(n=3)$. Hücre döngüsü düzenlenmesi, akım sitometri kullanılarak DNA'nın PI ile boyamast yoluyla incelendi. Hücre döngüsünün $G_{0} / G_{1}, S$ ve $G_{2} / M$ fazlarında biriken hücrelerin yüzdesi belirlendi. Barların üzerindeki yıldızlar (*), kontrol ile karşılaştırıldı ̆̆ında anlamlı olan farklılıkları göstermektedir $(* * * * p<0,0001)$.

\section{Ponatinibin MCF-7 Hücrelerinde miRNA Profili Üzerindeki Etkileri}

MCF-7 hücrelerinde, 4,59 $\mu \mathrm{M}$ ponatinibin meme kanseri ile ilişkili miRNA ifade profili üzerine etkileri qRT-PCR ile değerlendirildi. İfade seviyeleri araştır1lan 84 miRNA arasindan, let-7a-5p, miR-29a-3p, miR-7-5p, miR-125b-5p, miR-212-3p ifadelerinde ponatinib uygulamasını takiben anlamlı düzeyde artış olduğu saptandı $(p<0,05$, Şekil 5$)$. En belirgin artışın 24,99 kat ile let-7a-5p ifadesinde olduğu belirlendi. Ayrica, miR-210-3p, miR-19b-3p, miR-140-5p, miR181b-5p, miR-155-5p, miR-223-3p, miR-141-3p, miR-21-5p ifadelerinde ponatinib uygulamasını takiben anlamlı düzeyde azalma olduğu belirlendi $(p<0,05$, Şekil 5). En belirgin azalma 5,16 kat ile miR-210-3p ifadesinde gözlendi. Ponatinib uygulaması sonrasında MCF-7 hücrelerinde miR-19a-3p ifadesinin tamamen baskılandığı saptand1.

İfadelerinde anlamlı değişim belirlenen (Kat değişimi $\geq \pm 2$, ve $p<0,05)$ miRNA'ların hedef mRNA'ları ve sinyal yolakları DIANA miRPath v.3 veri tabanında analiz edildi ${ }^{16}$. İfadesi değişen miRNA'ların ilişkili olduğu 45 sinyal yolağı arasından, kanserde proteoglikanlar (hsa05205), Hippo sinyal yolağı (hsa04390), p53 sinyal yolağı (hsa04115), TGF-beta sinyal yolağı (hsa04350), kanser ilişkili yolaklar (hsa05200), PI3KAkt sinyal yolağı (hsa04151), prolaktin sinyal yolağ (hsa04917), hücre döngüsü (hsa04110), östrojen sinyal yolağı (hsa04915), mTOR sinyal yolağ (hsa04150) biyoinformatik analizlerine ilişkin veriler Tablo I'de verilmektedir. Her miRNA'nın sinyal yolakları içerisindeki hedef mRNA sayısı ise Tablo II'de özetlenmiştir. MCF-7 hücrelerinde ponatinib uygulaması sonrasında ifadesinin değiştiği belirlenen 14 miRNA'dan 13 miRNA'nın kanserde proteoglikanlar yolağı ile ilişkili toplamda 130 geni ve 9 miRNA'nın Hippo sinyal yolağı ile ilişkili toplamda 84 geni en yüksek anlamlılık düzeyi ile hedeflediği biyoinformatik analizler ile belirlendi (Tablo II).
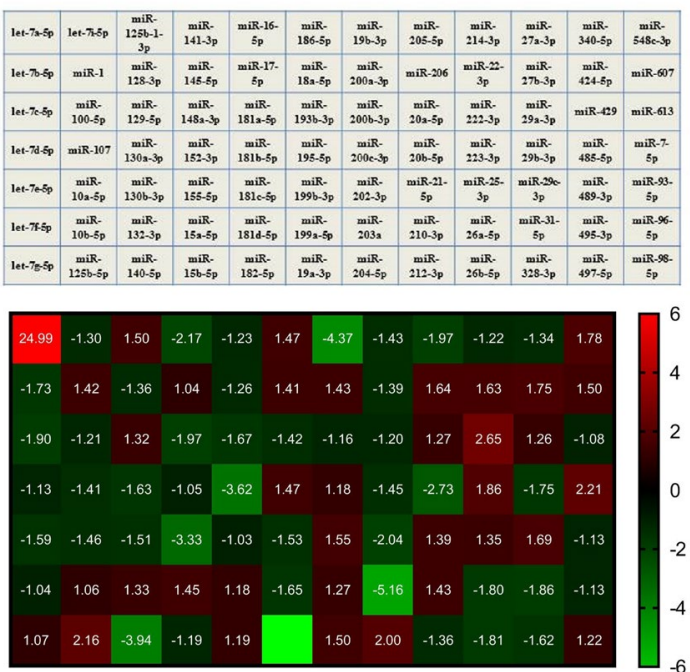

Şekil 5.

Ponatinibin MCF-7 hücrelerinde miRNA profili üzerindeki etkileri. $M C F-7$ hücreleri, ponatinib $\left(I C_{50}\right.$ : $4,59 \mu M)$ ile 72 saat süresince kültüre edildi $(n=3)$. miRNA ifadelerindeki düzenlenmeler $q R T-P C R$ ile değgerlendirildi. Kat değişimi $\geq \pm 2$, ve $p$ değeri $<0,05$ anlamlı kabul edilmiştir. miRNA isimleri üst panelde verilmiştir. Isı haritasında miRNA ifadelerindeki artışlar kırmızı, azalmalar yeşil renk ile ifade edilmektedir.

Tablo I. Ponatinibin MCF-7 hücrelerinde ifadesini değiştirdiği miRNA'lar ile ilişkili sinyal yolakları

\begin{tabular}{|clcc|}
\hline & KEGG yolağı & p değeri & miRNA \\
\hline I & Kanserde proteoglikanlar (hsa05205) & $<1 \mathrm{E}-325$ & 13 \\
III & Hippo sinyal yolağı (hsa04390) & $<1 \mathrm{E}-325$ & 9 \\
III & p53 sinyal yolağı (hsa04115) & $8,74 \mathrm{E}-13$ & 8 \\
IV & TGF-beta sinyal yolağı (hsa04350) & $2,32 \mathrm{E}-06$ & 6 \\
V & Kanser ilişkili yolaklar (hsa05200) & $6,86 \mathrm{E}-08$ & 5 \\
VI & PI3K-Akt sinyal yolağı (hsa04151) & $1,81 \mathrm{E}-04$ & 5 \\
VII & Prolaktin sinyal yolağı (hsa04917) & $2,53 \mathrm{E}-06$ & 5 \\
VIII & Hücre döngüsü (hsa04110) & $8,13 \mathrm{E}-11$ & 4 \\
IX & Östrojen sinyal yolağı (hsa04915) & $6,65 \mathrm{E}-03$ & 2 \\
X & mTOR sinyal yolağı (hsa04150) & $2,74 \mathrm{E}-02$ & 2 \\
\hline
\end{tabular}

MCF-7 hücrelerine ponatinib uygulamasını takiben ifadesi değişim gösteren 14 miRNA ile biyoinformatik analiz gerçekleștirilmiștir. Hedef sinyal yolağı ile ilişkili miRNA sayısı ve miRNA-sinyal yolağı ilişkisine ait $\mathrm{p}$ değerleri tabloda verilmektedir. KEGG yolak analizi DIANA miRPath v.3 veri tabanında gerçekleştirildi ${ }^{16}$ [http://snf-515788.vm.okeanos.grnet.gr/ (Son erişim tarihi: 28.10.2021)] 
Tablo II. Her miRNA'nın belirtilen sinyal yolakları içerisindeki hedef mRNA sayısı.

\begin{tabular}{|c|c|c|c|c|c|c|c|c|c|c|}
\hline \multicolumn{11}{|c|}{ Sinyal yolağı içerisindeki hedef mRNA sayısı } \\
\hline miRNA & I & II & III & IV & V & VI & VII & VIII & IX & $\mathbf{x}$ \\
\hline hsa-miR-141-3p & 20 & & 14 & & 43 & 38 & 9 & & & \\
\hline hsa-miR-29a-3p & 30 & 20 & 16 & & 55 & 53 & & & & \\
\hline hsa-miR-223-3p & 6 & & & & & & & & & 4 \\
\hline hsa-miR-7-5p & 40 & 32 & & & 66 & 57 & & & & \\
\hline hsa-miR-125b-5p & 20 & 21 & & & & & & & & \\
\hline hsa-miR-140-5p & 21 & 19 & 11 & 7 & & & & 14 & & \\
\hline hsa-miR-212-3p & 15 & 12 & & 11 & & & & 21 & & \\
\hline hsa-miR-181b-5p & 16 & 18 & 13 & & & & & & & \\
\hline hsa-miR-155-5p & 25 & & & 9 & & & 14 & & & \\
\hline hsa-miR-19a-3p & 44 & 23 & 20 & 15 & & 49 & 22 & & 20 & 16 \\
\hline hsa-miR-21-5p & 32 & 23 & 15 & & 49 & & 13 & 20 & & \\
\hline hsa-let-7a-5p & 49 & 42 & 23 & 27 & 79 & & & 43 & & \\
\hline hsa-miR-19b-3p & 35 & & 18 & 12 & & 42 & 17 & & 13 & \\
\hline hsa-miR-210-3p & & & & & & & & & & \\
\hline
\end{tabular}

MCF-7 hücrelerine ponatinib uygulamasını takiben ifadesi değişim gösteren 14 miRNA ile biyoinformatik analiz gerçekleştirilmiştir Her miRNA'nın hedef sinyal yolakları içerisindeki hedef mRNA sayısı tabloda özetlenmektedir. Sinyal yolaklarının sayısal kodlamas1 (I-X) Tablo I'e göre verilmiştir. KEGG yolak analizi DIANA miRPath v.3 veri tabanında gerçekleştirildi ${ }^{16}$ [http://snf515788.vm.okeanos.grnet.gr/ (Son erişim tarihi: 28.10.2021)].

\section{Tartışma ve Sonuç}

Meme kanserinin görülme sıklığının ve ölüm oranlarının yüksek seyretmesi nedeniyle ${ }^{2}$, mevcut tedavilerin düşük seçicilik ya da zamanla oluşan ilaç direnci gibi eksiklerini giderebilecek yeni stratejilerin belirlenmesine ihtiyaç vardır ${ }^{1}$. Bozulmuş FGFR, PDGFR, VEGFR düzenlenmesi meme kanseri için belirgin bir risk faktörleridir ve meme kanseri tedavisinde potansiyel hedef teşkil etmektedirler ${ }^{5-7}$. Ponatinib Src ailesi kinazlar1, c-Kit, PDGFR $\alpha$, VEGFR2, FGFR1 gibi kinazları da inhibe etmektedir ${ }^{10}$. Bu nedenle çalışmamizda meme kanseri hücrelerini hedeflemede kemoterapötik ajan olarak ponatinib seçilmiştir. Önceki çalışmamızda ponatinibin meme kanseri hücreleri üzerinde sitotoksik etkiler sergilediğini de belirlemiştik ${ }^{17}$. Shao ve ark. tarafindan yapılan in vitro çalışmada, ponatinibin meme kanseri hücrelerinin migrasyonunu ve mamosfer oluşumunu önemli ölçüde inhibe ettiği ortaya koyulmuştur $^{18}$. Ponatinibin PDGFR inhibisyonu aracılığ hedeflediği ve tamoksifen terapisinin etkinliğini arttır$\mathrm{d}_{1} \breve{g}_{1}$ belirlenmiştir ${ }^{19}$. Benzer şekilde ponatinib kombinasyonunun meme kanserinde doksorubisin uygulamasının etkinliğini arttırdığı da rapor edilmiştir ${ }^{20}$. Bu çalışmalar ışığında ponatinibin meme kanseri tedavisinde potansiyel bir terapi olabileceği görüşü mevcuttur. Ponatinibin meme kanseri üzerindeki etkileri ile ilgili çeşitli çalışmalar yapılmasına rağmen miRNA ekspresyon profili üzerindeki etkisi büyük ölçüde bilinmemektedir. Bu nedenle bu çalışmada, ÖR pozitif meme kanseri hücrelerinde ponatinib yanıtında yer alan miRNA'ları ve bunların proliferasyon, apoptoz ve diğer sinyal yolaklarındaki potansiyel işlevlerini tanımlamayı amaçladık.

Çalışmamızda, ponatinibin MCF-7 hücrelerinde belirgin düzeyde apoptozu indüklediği ortaya koyuldu. Bauer ve ark. yaptıkları çalışmada ${ }^{21}$, ponatinibin MCF-7 hücrelerinde hem Annexin V hem de aktif kaspaz 3 pozitif hücre yüzdesinde artışa neden olduğunu saptayarak doza bağlı olarak apoptozu indüklediğini belirlemişlerdir. Benzer şekilde çalışmamızda, MCF-7 hücrelerine ponatinib uygulamasının Annexin $\mathrm{V}$ pozitif hücrelerde artışa neden olmasına ek olarak apoptotik DNA kırıklarına sahip hücrelerin yüzdesindeki artışa da neden olduğu ortaya koyuldu. Ponatinib uygulaması ile ifadesi değişen miRNA'ların apoptotik prosesin düzenlenmesinde rolleri olan p53, TGF-beta, PI3K/Akt/mTOR sinyal yolakları ve kanser ilişkili yolaklar ile bağlantılı olduğu saptandı. Bu yolaklardan p53 transkripsiyon bağımlı ve bağımsız birçok mekanizma yoluyla apoptozu açıkça desteklerken ${ }^{22}$, TGFbeta diğer sinyal yolaklarıyla ilişkili olarak apoptozu indüklemektedir ${ }^{23}$. PI3K/Akt/mTOR yolağ1 ise antiapoptotik bir yolak olarak rol oynar ve hücre ölüm mekanizmasının çeşitli bileşenlerini doğrudan düzenleyerek hücre sağ kalımını destekler ${ }^{24}$. Bu sinyal yolaklarında rolü olan çok sayıda mRNA ile ilişkili olduğunu biyoinformatik analizler ile saptadığımız miR141-3p, meme kanseri hasta örneklerinde ve hücre hatlarında artmış ifade sergilemektedir ${ }^{25}$. Ayrıca, miR141-3p ifadesinin arttırılmasının meme kanseri hücrelerinde uzun kodlanmayan RNA (lncRNA) MEG3 ile düzenlenen apoptozu inhibe ettiği de rapor edilmiştir ${ }^{25}$. Kanser ilişkili yolaklarda rol oynadığını belirlediğimiz miRNA'lardan miR-29a-3p, tamoksifen dirençli meme kanseri hücrelerinde tümör baskılayıcı aktivite ile ilişkilendirilmiş ${ }^{26}$, miR-7-5p'in ise proteazom aktivatör alt birimi 3'ü hedefleyerek meme kanserinde in vitro ve in vivo apoptozu indüklediği bildirilmiştir ${ }^{27}$. OnkomiR miR-19a-3p'nin meme kanseri büyümesini ve koloni oluşumunu desteklediğ $\mathrm{i}^{28}$, miR-19b-3p'nin meme kanserinde PI3K-Akt yolağını inhibe ederek Src inhibitörü duyarlılığını arttırdığı ortaya koyulmuş$\operatorname{tur}^{29}$. Ponatinibin ifadelerini düzenlediği miRNA'ların potansiyel hedefleri olarak belirlenen sinyal yolakları meme kanseri hücrelerinde apoptozun indüklenmesinde rol oynuyor olabilir.

MCF-7 hücreleri üzerinde apoptotik etkisi olduğunu belirlediğimiz ponatinibin hücreler üzerindeki antiproliferatif etkileri de araştırıldı. Çalışmamızda 4,59 $\mu \mathrm{M}$ ponatinibin hücre proliferasyonunu 13 kattan fazla yavaşlattığ 1 ve bu anti-proliferatif etkinin hücre döngüsünün $\mathrm{G}_{0} / \mathrm{G}_{1}$ ve $\mathrm{S}$ evrelerinde meydana gelen tutulum kaynaklı olduğu ortaya koyuldu. Kim ve ark. tarafindan MCF-7 hücreleri ile yapılan çalışmada ${ }^{19}, 2$ $\mu \mathrm{M}$ ponatinibin $\mathrm{G}_{0} / \mathrm{G}_{1}$ tutulumuna neden olduğunu rapor edilmiştir. Çalışmamızdaki $\mathrm{S}$ evresindeki tutu- 


\section{Meme Kanserinde Ponatinib İlişkili miRNA'lar}

lumun ponatinib dozundan kaynaklandığını düşünmekteyiz. Ponatinib ile ifadesi değişen dört miRNA'nın hücre döngüsü düzenlenmesi ile ilişkili olduğu saptand1. Hücre döngüsü ilerlemesinde rolü olan 43 hedef mRNA ile ilişkilendirilen let-7a-5p ve 21 hedef mRNA ile ilişkilendirilen miR-212-3p ön plana çıkmaktadır. Ponatinib uygulaması sonrasında ifadesinde çok yüksek artış saptanan let-7a-5p'nin, onkogenik STAT3 yolağının baskılanmasında rol oynadığı ve sağlıklı dokulara kıyasla meme kanseri dokularında azalma gösterdiği kanıtlanmıştır ${ }^{30}$. Ayrıca Su ve ark. tarafindan yapılan çalışmada, hücre döngüsünün $\mathrm{G}_{1} / \mathrm{S}$ geçişinde kritik öneme sahip siklin D1 ifadesinin let-7 ailesini tarafından baskıladığı ortaya koyulmuştur ${ }^{31}$. Benzer şekilde Li ve ark. tarafından yapılan bir çalışmada ponatinib uygulaması sonrasında arttığını belirlediğimiz miR-212-3p'nin, MCF-7 hücrelerinde lncRNA LINC01977 aracilı proliferasyonu azalttığ bulunmuştur $^{32}$. Ayrıca, Li ve ark. meme kanseri hücrelerinde miR-212-3p inhibisyonunun anti-tümör ajan uygulamasının anti-proliferatif etkilerini tersine çevirdiğini ortaya koymuşlardır ${ }^{33}$. Ponatinib bu miRNA'ların ifadesini arttırarak meme kanseri hücrelerinin proliferasyonunu baskıliyor ve hücre döngüsünün $\mathrm{G}_{1} / \mathrm{S}$ geçişinin durduruyor olabilir.

Hippo sinyal yolağı, proliferasyon ve hücre ölümünü düzenleyerek doku büyümesini ve organ boyutunu kontrol eden bir sinyal kaskadından oluşur ${ }^{34}$. Tümör baskılayıcı nitelikteki yolağın baskılanması, transkripsiyonel aktivitenin düzenlenmesi sonucu kontrolsüz hücre proliferasyonuna ve apoptozdan kaçışa neden olur. Hippo sinyal yolağında kilit rol oynayan kinazların ve transkripsiyon koaktivatörlerinin ifade seviyeleri ile meme kanseri progresyonu arasında yakın ilişki vardır $^{34}$. Çalışmamızda MCF-7 hücrelerinde ponatinib ile ifadesi düzenlenen 9 miRNA'nın Hippo sinyal yolağı ile ilişkili olduğu belirlendi. Bunlar arasından, miR-21-5p'nin lncRNA LINC00968 tarafindan süngerlenerek ortamda azalmasının, Hippo sinyalizasyonunun negatif geri besleme düzenleyicisi olan SMAD7'nin birikimine yol açtığı bilinmektedir ${ }^{35}$ SMAD7 susturulması ise Hippo sinyalizasyonunu durdurarak hücre proliferasyonunu ve koloni oluşumunu arttırmaktadır ${ }^{35}$. Dolayısıyla, ponatinib ile MCF-7 hücrelerinde ifadesinin azaldığ 1 belirlenen miR-21-5p, tümör baskılayıcı Hippo sinyal yolağının aktivasyonuna katkıda bulunarak ponatinibin antikanser etkisinde rol oynuyor olabilir.

Çalıșmamızda kanserde proteoglikanlar yolağı MCF-7 hücrelerinde ponatinib ile ifadesi düzenlenen miRNA'lar ile en ilişkili yolak olarak belirlendi. Hem stroma hem de kanser hücreleri tarafindan salgılanan ekstrasellüler matriksin önemli bileşenleri proteoglikanlar tümörogenezin her aşamasında yer alırlar ${ }^{36}$. Hormon bağımlı meme kanserinde metastaz, epitelyal mezenkimal geçiş, anjiyogenez, ve tedaviye yanıt gibi pek çok mekanizmada rol oynamaktadır ${ }^{36}$. Östrojen bağımlı meme kanseri hücrelerinde bu yolağın miR-
NA'lar tarafında yüksek anlamlılıkla hedeflenmesi, ponatinib tedavisinin belirlenen yüksek anti-kanser etkinliğini açıklayabilir. Bunun yanında, meme kanserinde östrojenin etkisi ön plana çıksa da hipofiz hormonu prolaktin de meme kanseri ile ilişkilendirilmektedir $^{37}$. Çalışmamızda, MCF-7 hücrelerinde ponatinib ile ifadesi düzenlenen miRNA'ların östrojen ve prolaktin sinyal yolakları ile ilişkili olduğu belirlendi. Dolayısıyla hormon bağımlı bu yolakların ponatinib arac1lı miRNA regülasyonu ile hedeflenmesi hastal1ğın tedavi seyri açısından önemli bir sonuçtur.

Ponatinib ÖR pozitif meme kanseri hücrelerinde apoptozu indükleyerek, proliferasyonu baskılayarak ve hücre döngüsünü durdurarak güçlü anti-kanser aktivite sergilemektedir. Ponatinibin belirlenen yüksek antikanser etkilerinde miRNA'lar önemli rollere sahiptir. Olası miRNA-mRNA etkileşimlerine dayanarak meme kanserindeki hedef sinyal yolaklarının tanımlanması 1șığında, ponatinib tek başına veya diğer tedavilerle kombinasyon halinde meme kanseri tedavisi için potansiyel bir strateji olabilir.

Etik Kurul Onay Bilgisi: Çalışma için etik kurul onayına gerek yoktur.

Araştırmacı Katkı Beyanı: Fikir ve tasarım: Ç.K., Ç.B.A., C.G.; Veri toplama ve işleme: C.K., S.Y.S., T.B.O., B.Ö.Y., Z.M., C.C.K., B.G.B.; Analiz ve verilerin yorumlanması: Ç.K., C.G.; Makalenin önemli bölümlerinin yazılması: Ç.K.

Destek ve Teșekkür Beyanı:

Çalıșmaya ait proje bütçe desteği bulunmaktadır. Çıkar Çatışması Beyanı:

Makale yazarlarının çıkar çatışması beyanı yoktur.

\section{Kaynaklar}

1. Arya GC, Kaur K, Jaitak V. Isoxazole derivatives as anticancer agent: A review on synthetic strategies, mechanism of action and SAR studies. Eur J Med Chem 2021;221:113511.

2. Siegel RL, Miller KD, Jemal A. Cancer statistics, 2019. CA Cancer J Clin 2019;69(1):7-34.

3. Lumachi F, Santeufemia DA, Basso SM. Current medical treatment of estrogen receptor-positive breast cancer. World J Biol Chem 2015;6(3):231-9.

4. Eric I, Petek Eric A, Kristek J, Koprivcic I, Babic M. Breast Cancer in Young Women: Pathologic and Immunohistochemical Features. Acta Clin Croat 2018;57(3):497-502.

5. Dickson C, Spencer-Dene B, Dillon C, Fantl V. Tyrosine kinase signalling in breast cancer: fibroblast growth factors and their receptors. Breast Cancer Res 2000;2(3):191-6.

6. Jitariu AA, Raica M, Cimpean AM, Suciu SC. The role of PDGF-B/PDGFR-BETA axis in the normal development and carcinogenesis of the breast. Crit Rev Oncol Hematol 2018;131:46-52.

7. Singh DD, Yadav DK. TNBC: Potential Targeting of Multiple Receptors for a Therapeutic Breakthrough, Nanomedicine, and Immunotherapy. Biomedicines 2021;9(8).

8. Huang WS, Metcalf CA, Sundaramoorthi R, Wang Y, Zou D, Thomas RM, ve ark. Discovery of 3-[2-(imidazo[1,2b]pyridazin-3-yl)ethynyl]-4-methyl-N- $\{4-[$ (4-methylpiperazin1-y 1)methyl]-3-(trifluoromethyl)phenyl \}benzamide (AP24534), a potent, orally active pan-inhibitor of breakpoint cluster re- 


\section{Ç. Kayabaşı, ark.}

gion-abelson (BCR-ABL) kinase including the T315I gatekeeper mutant. J Med Chem 2010;53(12):4701-19.

9. Zhou T, Commodore L, Huang WS, Wang Y, Thomas M, Keats J, ve ark. Structural mechanism of the Pan-BCR-ABL inhibitor ponatinib (AP24534): lessons for overcoming kinase inhibitor resistance. Chem Biol Drug Des 2011;77(1):1-11.

10. O'Hare T, Shakespeare WC, Zhu X, Eide CA, Rivera VM, Wang F, ve ark. AP24534, a pan-BCR-ABL inhibitor for chronic myeloid leukemia, potently inhibits the T315I mutant and overcomes mutation-based resistance. Cancer Cell 2009;16(5):401-12.

11. Musumeci F, Greco C, Grossi G, Molinari A, Schenone S Recent Studies on Ponatinib in Cancers Other Than Chronic Myeloid Leukemia. Cancers (Basel) 2018;10(11).

12. Bartel DP. MicroRNAs: genomics, biogenesis, mechanism, and function. Cell 2004;116(2):281-97.

13. Iorio MV, Croce CM. MicroRNAs in cancer: small molecules with a huge impact. J Clin Oncol 2009;27(34):5848-56.

14. Esquela-Kerscher A, Slack FJ. Oncomirs - microRNAs with a role in cancer. Nat Rev Cancer 2006;6(4):259-69.

15. Wong JS, Cheah YK. Potential miRNAs for miRNA-Based Therapeutics in Breast Cancer. Noncoding RNA 2020;6(3).

16. Vlachos IS, Zagganas K, Paraskevopoulou MD, Georgakilas G, Karagkouni D, Vergoulis T, ve ark. DIANA-miRPath v3.0: deciphering microRNA function with experimental support. Nucleic Acids Res 2015;43(W1):W460-6.

17. Okcanoğlu TB, Kayabașı C, Süslüer SY, Gündüz C. The Relationship Between Long Non-Coding RNA Expressions and Ponatinib in Breast Cancer. Cyprus Journal of Medical Sciences 2019;4(2):125-30

18. Shao W, Li S, Li L, Lin K, Liu X, Wang H, ve ark. Chemical genomics reveals inhibition of breast cancer lung metastasis by Ponatinib via c-Jun. Protein Cell 2019;10(3):161-77.

19. Kim S, You D, Jeong Y, Yoon SY, Kim SA, Lee JE. Inhibition of platelet-derived growth factor receptor synergistically increases the pharmacological effect of tamoxifen in estrogen receptor alpha positive breast cancer. Oncol Lett 2021;21(4):294.

20. Kim S, You D, Jeong Y, Yoon SY, Kim SA, Lee JE. Inhibition of platelet-derived growth factor $\mathrm{C}$ and their receptors additionally increases doxorubicin effects in triple-negative breast cancer cells. Eur J Pharmacol 2021;895:173868.

21. Bauer K, Berger D, Zielinski CC, Valent P, Grunt TW. Hitting two oncogenic machineries in cancer cells: cooperative effects of the multi-kinase inhibitor ponatinib and the BET bromodomain blockers JQ1 or dBET1 on human carcinoma cells. Oncotarget 2018;9(41):26491-506.

22. Fridman JS, Lowe SW. Control of apoptosis by p53. Oncogene 2003;22(56):9030-40.

23. Zhao B, Chen YG. Regulation of TGF-beta Signal Transduction. Scientifica (Cairo) 2014;2014:874065
24. Vivanco I, Sawyers CL. The phosphatidylinositol 3-Kinase AKT pathway in human cancer. Nat Rev Cancer 2002;2(7):489-501.

25. Dong S, Ma M, Li M, Guo Y, Zuo X, Gu X, ve ark. LncRNA MEG3 regulates breast cancer proliferation and apoptosis through miR-141-3p/RBMS3 axis. Genomics 2021;113(4):1689704.

26. Muluhngwi P, Krishna A, Vittitow SL, Napier JT, Richardson $\mathrm{KM}$, Ellis $\mathrm{M}$, ve ark. Tamoxifen differentially regulates miR29b-1 and miR-29a expression depending on endocrinesensitivity in breast cancer cells. Cancer Lett 2017;388:230-8.

27. Shi Y, Luo X, Li P, Tan J, Wang X, Xiang T, ve ark. miR-7-5p suppresses cell proliferation and induces apoptosis of breast cancer cells mainly by targeting REGgamma. Cancer Lett 2015;358(1):27-36.

28. Lee S, Lee H, Bae H, Choi EH, Kim SJ. Epigenetic silencing of miR-19a-3p by cold atmospheric plasma contributes to proliferation inhibition of the MCF-7 breast cancer cell. Sci Rep 2016;6:30005.

29. Jin J, Sun Z, Yang F, Tang L, Chen W, Guan X. miR-19b-3p inhibits breast cancer cell proliferation and reverses saracatinibresistance by regulating PI3K/Akt pathway. Arch Biochem Biophys 2018;645:54-60.

30. Yao A, Xiang Y, Si YR, Fan LJ, Li JP, Li H, ve ark. PKM2 promotes glucose metabolism through a let-7a$5 \mathrm{p} / \mathrm{Stat} 3 / \mathrm{hnRNP}-\mathrm{A} 1$ regulatory feedback loop in breast cancer cells. J Cell Biochem 2019;120(4):6542-54.

31. Sun H, Ding C, Zhang H, Gao J. Let7 miRNAs sensitize breast cancer stem cells to radiationinduced repression through inhibition of the cyclin D1/Akt1/Wnt1 signaling pathway. Mol Med Rep 2016;14(4):3285-92.

32. Li Z, Li Y, Wang $\mathrm{X}$, Liang $\mathrm{Y}$, Luo $\mathrm{D}$, Han $\mathrm{D}$, ve ark. LINC01977 Promotes Breast Cancer Progression and Chemoresistance to Doxorubicin by Targeting miR-212-3p/GOLM1 Axis. Front Oncol 2021;11:657094.

33. Li X, Zou ZZ, Wen M, Xie YZ, Peng KJ, Luo T, ve ark. ZLM7 inhibits the occurrence and angiogenesis of breast cancer through miR-212-3p/Sp1/VEGFA signal axis. Mol Med 2020;26(1):109.

34. Wu Y, Li M, Lin J, Hu C. Hippo/TEAD4 signaling pathway as a potential target for the treatment of breast cancer. Oncol Lett 2021;21(4):313

35. Zhu Y, Bo H, Chen Z, Li J, He D, Xiao M, ve ark. LINC00968 can inhibit the progression of lung adenocarcinoma through the miR-21-5p/SMAD7 signal axis. Aging (Albany NY) 2020;12(21):21904-22.

36. Tzanakakis G, Giatagana EM, Kuskov A, Berdiaki A, Tsatsakis AM, Neagu M, ve ark. Proteoglycans in the Pathogenesis of Hormone-Dependent Cancers: Mediators and Effectors. Cancers (Basel) 2020;12(9).

37. Subramani R, Nandy SB, Pedroza DA, Lakshmanaswamy R. Role of Growth Hormone in Breast Cancer. Endocrinology 2017;158(6):1543-55 